\title{
STUDYING THE CHINESE MINORITIES: A REVIEW
}

Charles A. Coppe1

Southeast Asia's Chinese Minorities

by Mary F. Somers Heidhues

Melbourne: Longman, 1974.

One must sympathize with any author who tries to write about the Chinese minorities in Southeast Asia as a whole. On the one hand, they seem to present a unity or at least to call for comparative treatment. Most of them, after a11, do originate from the same southern Chinese provinces of Fukien and Kwangtung. They play a disproportionately large role in the business world of most of the Southeast Asian countries, and their trading and financial network throughout the region is a potent force which crosses national boundaries. Furthermore, the Chinese minorities have come to be seen as a "problem" by the governments of most of these countries, while the Chinese themselves have been subject to legislative and administrative discrimination, racial prejudice, and occasional outbursts of violence.

Nonetheless, there are formidable difficulties facing anyone who wants to write about the Southeast Asian Chinese in general. The Chinese migrants themselves were a heterogeneous lot, speaking several mutually unintelligible languages (or dialects, so-called), and the settlements of Chinese which grew up in different parts of the region have had separate histories. Some of these communities have been established for centuries, while others are creations of the last hundred years. The degree to which they have been assimilated or influenced by the cultures of local societies in different parts of Southeast Asia varies enormously, reflecting not only the length of Chinese settlement in the area concerned, but also the diversity of the Southeast Asian peoples themselves and many other factors. Not least among the latter have been the differing policies pursued by the various European colonial administrations which governed al1 the countries of the region except Thailand, and the differing policies pursued by the various Southeast Asian governments which succeeded them.

Apart from the tensions created by the need to reconcile these and other diversities of the overseas Chinese with their elements of unity and uniformity, one is confronted with a babel of sources, both primary and secondary, in many European and Asian languages. A student of the Southeast Asian Chinese is inevitably more familiar with the Chinese of one (or rarely two) of the countries concerned. His perception of the Chinese in other countries is almost inevitably shaped by his understanding of the Chinese in the country with which he is most familiar, and the languages at his command usually reflect his area of specialization. For these reasons it is regrettable that there is 
as yet no collaborative study of the Southeast Asian Chinese analogous to the general Southeast Asian history, In Search of Southeast Asia. 1

Southeast Asia's Chinese Minorities by Mary F. Somers Heidhues 2 bears the imprint of its author's greater familiarity with the Indonesian Chinese. Not only does she devote more space to them than to any of the other Chinese minorities, but her approach to the Chinese in other countries is colored by the preoccupations of the Indonesian Chinese themselves and those of Western scholars who have written about them (especially in the English language). Her book does, nonetheless, rank as the best short work in English on the Southeast Asian Chinese so far. Its nearest competitor, Lea Williams's The Future of the overseas Chinese in Southeast $A s i a^{3}$ is marred by the dubious central thesis that the problems of the overseas Chinese will be resolved if only they participate fully in the politics and government of the country in which they live. The third book in the field, C. P. Fitzgerald's The Third China, ${ }^{4}$ runs a poor last, betraying a lack of familiarity with the Southeast Asian countries themselves and the scholarly literature on the Southeast Asian Chinese. Somers Heidhues, by contrast, makes good use of the work of leading specialists on the Chinese in other Southeast Asian countries, such as Skinner (Thailand), W. E. Willmott (Cambodia), and Wickberg (Philippines). In addition, in her chapter on China and the overseas Chinese, she was able to take advantage of Stephen Fitzgerald's important book on that subject. 5 Nor does she propound any simple panacea by which the Chinese can solve their problems, but judiciously concludes: "In the end, nothing which the ethnic Chinese themselves do can fully account for the feeling against them; nothing they can do can fully counteract that sentiment."

In deference to the presumed interests of the readers of this journal and having regard to the area of specialization of the author of Southeast Asia's Chinese Minorities (and likewise of the present reviewer), the discussion which follows will focus primarily on the Indonesian Chinese. (The points raised, however, may well have a wider application.) This procedure is, of course, unfair to the author since her book is short (125 pages) and much wider in scope, but the purpose is to raise certain fundamental questions about our approach to the study of the Chinese minority. ${ }^{6}$

${ }^{1}$ D. J. Steinberg, et al., In Search of Southeast Asia (Kuala Lumpur: Oxford University Press, 1971).

${ }^{2}$ Mary K. Somers Heidhues, Southeast Asia's Chinese Minorities (Melbourne: Longman, 1974).

${ }^{3}$ Lea E. Williams, The Future of the Overseas Chinese in Southeast Asia (New York: McGraw-Hil1, 1966).

${ }^{4} \mathrm{C}$. P. Fitzgerald, The Third China (Melbourne: Angus \& Robertson, 1965). I have not included Victor Purcell's classic The Chinese in Southeast Asia, 2nd rev. ed. (London: Oxford University Press, 1965) in this discussion because of its much greater scale.

5Stephen Fitzgerald, China and the Overseas Chinese (Cambridge: Cambridge University Press, 1972).

${ }^{6}$ I should make it clear that in most of what follows I am not singling out Mary Somers Heidhues for special criticism. Most of my own work and that of other Anglophone writers on the Indonesian Chinese is equally vulnerable. 
Southeast Asia's Chinese Minorities is in the mainstream of Ang1ophone scholarship on the Indonesian Chinese. More precisely it represents, as does the same author's regrettably unpublished doctoral dissertation, 7 a confluence of the two major currents of that scholarship. On the one hand, one has anthropological and sociological interest in the processes of acculturation and assimilation among the Chinese. On the other hand, there is concern with their political life, their loyalty to Indonesia, and the outbreaks of violence against them. Lurking in the background of these scholarly preoccupations, in addition to a humane concern for the fate of the Indonesian Chinese, one can surely detect the influence of the Cold war and the fear (not necessarily that of the scholars themselves) that these Chinese may be or become a fifth column for peking. The two currents converge in the optimistic if not explicitly stated assumption that assimilation is the key to solving every problem. If only they can be assimilated, the Chinese will be set free from further discrimination and violence, as well as from any lingering loyalty to Peking.

Within Indonesia itself, this happy solution was advocated quite explicitly by a relatively small group of Indonesian Chinese and was eventually taken up with pleasure by the Suharto government. ${ }^{9}$ The alternative integrationist policy of accepting the peranakan (1ocalborn or even "mixed blood") Chinese as a sukubangsa (ethnic group) with its own culture within the broader Indonesian nation was discredited by the identification of Baperki (Badan Permusjawaratan Kewarganegaraan Indonesia, Consultative Body for Indonesian Citizenship) with the left, particularly with Sukarno and the PKI. Thus, in the name of assimilation, the culture and social organizations of Chinese society in Indonesia, whether totok (1iterally, "pure") or peranakan, had to be dismantled and eradicated.

One weakness in the assimilationist case, both in scholarly writing and in the Indonesian political arena, has been the relative neglect of structural factors in Indonesian society, especially social class and bureaucratic power. It is not that Somers Heidhues ignores the economic role of the Southeast Asian Chinese. Her chapter on this subject is the longest in the book and she argues that their involvement in commercial activity is their first and most important common characteristic. In an excellent overview of the range of economic activities they engage in, she expressly rejects the "plural society" model which equates class with race.

However, we have yet to see an analysis of Indonesian social structure which satisfactorily encompasses the Chinese. It is not

7Mary F. Somers, "Peranakan Chinese Politics in Indonesia" (Ph.D. dissertation, Cornell University, 1965).

"See my"Select Bibliography on the Indonesian Chinese," in J. A. C. Mackie (ed.), The Chinese in Indonesia: Five Essays (Melbourne: Nelson, 1976) and the essays by Mackie and myself in the same volume.

${ }^{9}$ The most detailed study of the political situation of the Indonesian Chi nese and of governmental policy toward them in the post-1965 period is my own unpublished dissertation: Charles A. Coppe1, "The Indonesian Chinese in the Sixties: A Study of an Ethnic Minority in a Period of Turbulent Political Change" (Ph.D. dissertation, Monash University, 1975). 
enough to delineate Chinese occupational differentiation, as Somers Heidhues does, although this differentiation is frequently ignored by others. It is undeniable that some Chinese are among the principal beneficiaries of the unequal distribution of wealth in Indonesia today. We are, however, woefully ill-informed about the extent to which this is true. It is strongly to be suspected that we have been holding fast to a picture of Indonesian society which is forty years out of date, given the paucity of reliable data available on an ethnic basis in the post-independence period. Much wealth as well as political power has passed into indigenous Indonesian hands since independence, especially in the last ten years, but we have no detailed studies which can document it. We will not get a realistic picture of the place of the Chinese in the Indonesian class structure and economy by confining our attention to the Chinese as an object of study, far less if we beg the question by treating them as a "commercial bourgeoisie," as Ben Anderson has suggested that we should. ${ }^{\circ}$ Whatever else is obscure, it seems clear that the Chinese are a racial minority which includes a large and important commercial bourgeoisie, but it would be just as misleading to attach that label to all Chinese as it would be to ignore the indigenous elements of the same class.

This brings us to the subject of race relations. One of the most persuasive theories seeking to explain anti-Sinicism is Wertheim's model of economic competition on an ethnic group basis.11 Here again we are handicapped by a lack of recent knowledge about the extent to which patterns have changed, especially in the last two decades. We need detailed studies which can tell us to what extent business concerns in Indonesia are still organized on an ethnically exclusive basis and to what extent interethnic partnerships have entered the field. An unpublished LEKNAS study of entrepreneurs recently conducted by Mely Tan suggests that ethnic exclusiveness (whether of Chinese or pribumi, indigenous groups) in business enterprises depends to an important extent upon the nature of the business. Where the business is based on trust, exclusiveness will be the rule. Not even the peranakan Chinese, far less the pribumi Indonesians, can break into the totok Chinese monopoly in banking. Similarly, ethnic exclusiveness is present (among both Chinese and pribumi) in the field of trade, though to a less extreme degree. But where the business depends less upon trust and more upon technical expertise, technical qualifications increasingly override ethnic considerations. 12

A curious oversight in the literature about race relations in Indonesia is that other "trading minority," the Arabs. Although the 1930 census data suggest that, as a group, the Arabs even more closely approximate a commercial bourgeoisie than do the Chinese, there has

10B. Anderson, "American Values and Research on Indonesia" (Paper delivered to the annual meeting of the American Association for Asian Studies, March 1971).

${ }^{11} \mathrm{~W}$. F. Wertheim, "The Trading Minorities in Southeast Asia," in his East-West Parallels (The Hague: Van Hoeve, 1964). Somers Heidhues curiously attributes the theory to "the work of Geertz, and others."

12 "Exclusiveness" is a dirty word in Indonesia. It is frequently forgotten that many small businesses are ethnically exclusive because they are family concerns. They are just as exclusive with regard to unrelated members of their own ethnic group as they are to members of other groups. 
been a relative lack of anti-Arab sentiment analogous to anti-Sinicism. This suggests that noneconomic factors must play an important part in the phenomenon. Is there any general theoretical explanation which can account for hostility being directed primarily against one of two "middleman minorities," such as the Chinese rather than the Arabs in Indonesia, or the Vietnamese and Indians rather than the Chinese in Cambodia and Burma, respectively? Is it simply a function of relative size? Or should one take into account, in the case of the Arabs, such cultural factors as the Arab origins of the Moslem religion? Or, in the case of the Chinese, such political factors as the proximity of China and the very divergent ideological orientations of the Chinese and Indonesian governments?

The benign view of China's intentions toward the overseas Chinese projected by Stephen Fitzgerald has had scant support in Indonesia. A continuing fear of Chinese subversion and illegal reentry into Indonesia by Chinese who fled to China in the last two decades has given rise to periodic reregistration of aliens (often involving Indonesiancitizen Chinese as we11, on the grounds that illegal immigrants have obtained forged citizenship papers) and has bedeviled the issue of restoring normal relations between Indonesia and China. A recent book by an Indonesian intelligence specialist on Chinese affairs displays the same old concern with the Chinese as a security problem. The fear of the Chinese as a fifth column is still very much alive in Indonesian military circles.13

Turning to the political activity of the Indonesian Chinese themselves, the assessment of Somers Heidhues (and this reviewer as well, for that matter) that the assimilationist movement had been "pushed off the scene" by late 1967 has proved to be premature. In August 1974 , a body known as the Badan Pembina Kesatuan Bangsa (BPKB, Organization for the Creation of National Unity) was formed under the authority of the governor of Jakarta. Including several leaders of a former assimilationist organization (LPKB), it is oriented toward research and social action. The stimulus for its formation seems to have been the rioting in Jakarta in January 1974 and a growing consciousness of the widening gap between the rich and the poor. A BPKB-sponsored forum in June 1975 to discuss the role that national entrepreneurs could play in bringing about national unity attracted leading Chinese and pribumi businessmen as well as a number of journalists and academics. The outcome was the establishment of a foundation (KARPENAS) to promote ongoing intercourse between Chinese and pribumi businessmen and to subsidize economically weak businessmen, such as those adversely affected by the construction of new multistory shopping centers. ${ }^{14}$

The $B P K B$ has also sponsored research. Detailed surveys have been made into Chinese-pribumi relations in two West Jakarta kelurahan (ward), one in Taman Sari and the other in Jembatan Lima. The research is being followed up by programs to provide joint recreational facili-

13W. D. Soekisman, Masalah Cina di Indonesia, 2nd rev. ed. (Jakarta: Yayasan Penelitian Masalah Asia, 1975).

${ }^{14}$ Can one detect here a move from ethnic to class alignments? See Hasiz Lengkap Diskusi Peranan Pengusaha Nasional dalam Pembangunan Ekonomi untuk Mewujudkan Kesatuan Bangsa (Jakarta: KADIN \& BPKB, June 11-12, 1975). 
ties for young pribumi and Chinese residents and to propagandize the assimilationist concept of national unity. ${ }^{15}$

The interest in assimilation has also inspired a number of student theses at Indonesian universities, most notably in the anthropology department of the University of Indonesia, and a few of them have been published as monographs.16 As one Indonesian reviewer has commented, it is regrettable that most studies of the Indonesian Chinese have been written by Westerners or the Indonesian Chinese themselves. 17 It is encouraging to find that several of these Indonesian theses were written by indigenous Indonesians, including one interesting survey research project among the Chinese of Blora. ${ }^{18}$

The discussion until how has proceeded largely within the conceptual framework of Somers Heidhues's book, while taking account of more recent developments. This approach, which has been categorized as being within the mainstream of Anglophone scholarship on the Indonesian Chinese, has its dangers. If we confine ourselves to the study of the Chinese as a political problem, and particularly if the resolution of the problem is seen as lying in the elimination of the Chinese as a discrete social group with a distinctive culture of their own, is there not some similarity in our approach to that of those development theorists who, with enthusiasm or regret, proceed on the assumption that the peasantry is on the road to extinction--a case of "academic genocide," as Rex Mortimer has called it? ${ }^{19}$

It is striking how little we learn from Somers Heidhues's chapter on assimilation about the nature of the Chinese societies and cultures which are to be abandoned. We are told that the peranakan Chinese of Java acculturated but did not assimilate to indigenous society, but the

${ }^{15}$ Laporan Penelitian Hubungan Sosial di Kelurahan Taman Sari Jakarta (Jakarta: BPKB, 1975); and Hasil-hasil Lokakarya Pembinaan Hubungan Sosial dalam rangka Pembinaan Kesatuan Bangsa di WiZayah DKI Jakarta (Jakarta: BPKB, 1976).

${ }^{16} \mathrm{~A}$ number of these are listed in Pauline Ratna Hendrati, Daftar Kepustakaan Selektif tentang Golongan Etnis Tionghoa di Indonesia sejak 1945 (Jakarta: LEKNASLIPI, 1975).

17Gondomono, "Tinjauan Buku: Masalah Cina di Indonesia," Prisma, 5, 8 (August 1976), pp. 80-85.

18Hari Purwanto Soewardi, "Golongan Minoritas Cina di Kecamatan Kota Blora-Suatu penelitian mengenai masalah akomodasi pada tahun 1972" (anthropology thesis, Gajah Mada University, 1973). Another interesting survey, by R. H. Pardoko and Astuti Indroes, Pengetahuan, Sikap dan Praktek Keluarga Berencana pada Golongan Minoritas Cina di Jowa Timur (Surabaya: Lembaga Kesehatan Nasiona1, 1974), provides evidence against the commonly held view in Indonesia that ethnic Chinese do not use family planning as much as pribumi Indonesians. This study shows that the percentage using family planning was higher among Chinese, but that they relied mostly on private doctors rather than on government clinics.

${ }^{19} \mathrm{~A}$ similar parallel can be drawn with those who seek to eradicate Javanese mysticism in the name of modernization. See A. M. Sievers, The Mystical World of Indonesia: Culture and Economic Development in Conflict (Baltimore: Johns Hopkins University Press, 1974) and the response by M. Slamet, "Priyayi Value Conflict," in J. A. C. Mackie (ed.), Religion and Social Ethos in Indonesia (Clayton, Vic.: Monash University Centre of Southeast Asian Studies, 1977). 
content of their mestizo culture is given scant treatment. We are not even referred, in this connection, to the major studies available in English of particular Chinese communities in Java. 20

There is another way to study the Indonesian Chinese (and those of other Southeast Asian countries). This is to approach their history in all its richness and complexity, without putting politics forever in center stage. A good deal of work of this kind has already been done, but Anglophone scholarship has by and large ignored it. The peranakan Chinese of Java in particular have had an extensive literate culture which is worthy of study in its own right, not merely for the light it throws on their political life. Precious little has been published in English about their language and 1iterature, their religious life, or their artistic achievements.21 By the same token, where is the basic research in English on the history of the Indonesian Chinese, using the evidence of Chinese travelers to Indonesia, inscriptions in Chinese temples and on tombstones, Dutch archival materials and journal articles, and the writings of the Chinese themselves?22 Anglophone scholarship on the Indonesian Chinese has been narrow in scope and parochial in its use of sources.23

But should we study the Chinese as such at all? There are also dangers in looking at the Chinese minority in isolation. It may well be that we have exaggerated the extent to which Dutch colonial policies

${ }^{20} \mathrm{E} . \mathrm{g}$., Donald E. Willmott, The Chinese of Semarang (Ithaca: Cornell University Press, 1960) and Giok-1an Tan, The Chinese of Sukabumi (Ithaca: Cornell Modern Indonesia Project, Monograph Series 31, 1963).

${ }^{21} \mathrm{Cf}$. C1. Lombard-Salmon, "Le sjair de 1'Association chinoise' de Batavia (1905)," Archipel, 2 (1971), pp. 55-100; "Société peranakan et Utopie: Deux romans sino-malais," Archipel, 3 (1972), pp. 169-95; "Aux origines de la littérature sinomalaise: Un sjair publicitaire de 1886," Archipel, 8 (1974), pp. 155-86; and Denys Lombard, "La grammaire de Lie Kim Hok (1884)," in J. M. C. Thomas and L. Bernot (eds.), Langues et techniques, nature et société (Paris: K1inckseck, 1972), II, pp. 197-203 (for literature and language). C1. Lombard-Salmon, "A propos de quelques cultes chinois particuliers à Java," Arts Asiatiques, 26 (1973), pp. 243-264; "Une morale en images: Les peintures murales du Xie-Tian-Gong de Bandung,"Archipel, 11 (1976), pp. 167-76 (for religion). On Chinese religion, see also D. E. Willmott, The Chinese of Semarang, and Leo Suryadinata, "Confucianism in Indonesia: Past and Present," Southeast Asia, 3, 3 (1974), pp. 881-903, and my "Contemporary Confucianism in Indonesia" (paper presented to the seventh conference of the International Association of Historians of Asia, Bangkok, August, 1977).

${ }^{22} \mathrm{Cl}$. and D. Lombard-Salmon, "A propos de quelques stèles chinoises récemment retrouvées à Banten (Java ouest)," Archipel, 9 (1975), pp. 99-127; Cl. Lombard-Salmon, "A propos de quelques tombes chinoises d'Indonésie des XVIIe et XVIIIe siècles," Archipel, 12 (1976), pp. 207-18, are recent and rare examples of the use of epigraphy in the history of the Indonesian Chinese. This work is urgent, because much of the material is rapidly disappearing. Apart from the Dutch archives, much of the material listed in G. A. Nagelkerke, A Selected Bibliography of the Chinese in Indonesia 17401974 (Leiden: Library, Royal Institute of Linguistics and Anthropology, 1975), has not been touched by historians of the Indonesian Chinese.

${ }^{23}$ The scarcity of non-English language works in Somers Heidhues's bibliography is symptonatic of this parochialism. It is not that she does not expect her readers to have access to works in other languages; she includes two references each in German and Indonesian, one each in French and Dutch. 
succeeded in keeping Chinese and indigenous Indonesians separate. The extent of acculturation among the peranakan Chinese should warn us that interaction between these two groups must have been far from insignificant. The new light thrown on the origins of peranakan Chinese literature by Claudine Lombard-Salmon should not obscure the fact that at least some of the early peranakan Chinese authors collaborated actively with Indonesians and Dutch Eurasians in publishing, writing, and journalism.24 Neither should we assume that the readers of their books and of the peranakan Chinese press in this century were exclusively Chinese.25 There are interesting examples of mutual interaction between Chinese and Indonesian in religious life 26 and it is likely that similar examples could be found in many fields. We should always bear in mind that acculturation is not necessarily a one-way affair.27

If we ignore the extent of interaction between Chinese and indigenous Indonesians in the past, except when it has involved hostility and violence, we are not merely denying the Chinese their rightful place as a part of Indonesian history. We are, in effect, continuing the colonial policy of attempting to segregate them from the Indonesians and, in the process, lessening our understanding of Indonesian history as a whole. The Chinese, like other ethnic groups in Indonesia, have had a separate history of their own. (Separate histories, we should say, since there is little shared history among the Chinese of Java, the goldminers and farmers of West Kalimantan, and the fishermen of Bagan Siapiapi, to name but a few examples.) Unlike other ethnic groups, however, they have lacked a separate territory of their own, and this fact has meant that their interaction with the other ethnic groups has been longer and more intensive than interaction among the Indonesian ethnic groups themselves.

Research should be directed not only toward the Chinese as a separate group but also as a part of Indonesian society and its history. The historiographical or methodological problem raised by such research differs little from the problem of reconciling regional history with Indonesian history as a whole. It is easy to give examples of how it can be done. Reference has already been made to Mely Tan's study of Chinese and pribumi entrepreneurs. Lance Castles' study of the kretek industry of Kudus does not ignore the Chinese role in it. A history of the

${ }^{24} \mathrm{C}$. W. Watson, "Some Preliminary Remarks on the Antecedents of Modern Indonesian Literature," Bijdragen tot de taal-, Zand-en volkenkunde, 127, 4 (1971), pp. 417-33. For the press, Leo Suryadinata, The Fre-World War II Peranakan Chinese Press: A Preziminary Survey, Papers in International Studies, Southeast Asia Series No. 18 (Athens: Ohio University, 1971). pp. $32-40$.

25Jakob Sumardjo, "Nove1-novel populer Indonesia," Prisma, 6, 6 (June 1977),

${ }^{26}$ Examples of the intermingling or coexistence of Chinese and indigenous religious cults may be found in $\mathrm{Cl}$. Lombard-Salmon, "A propos de quelques cultes," and "A propos de quelques tombes."

${ }^{27 G i o k-1 a n ~ T a n, ~ T h e ~ C h i n e s e ~ o f ~ S u k a b u m i, ~ i l l u s t r a t e s ~ t h e ~ C h i n e s e ~ i n f l u e n c e ~ o n ~}$ Indonesian cuisine; for language, see Philip Leo, Chinese Loanwords Spoken by the Inhabitants of the City of Jakarta (Jakarta: LRKN-LIPI, Seri Data Dasar 7, 1975). The Confucianist organization NATAKIN claims to be making Javanese converts to its faith, aided, no doubt, by their incorporation of such Javanese concepts as tepa selira and mawas diri; see my "Contemporary Confucianism in Indonesia." 
Indonesian-language press or of Indonesian-language 1iterature can incorporate the peranakan Chinese press and literature as a part of it.

By incorporating the Chinese within these broader or cross-cutting frames of reference and not overemphasizing the political aspects, scholarly research might even help to provide a solution to the "Chinese problem" itself, precisely by abandoning an obsessive concern with it. The full acceptance of the Chinese as a part of the Indonesian nation will not come about through a magical disappearance of the Chinese by a mystical process of assimilation, at least not for many generations. Indonesians are sometimes baffled by the failure of the Chinese of West Kalimantan to assimilate. In a city like Pontianak, where a majority of the population is Chinese and Chinese-speaking, and even many Dayaks speak Chinese, the reason is obvious. Many Indonesians take pride in the sporting prowess of their badminton champions who are of Chinese descent. When the time comes that they can take similar pride in the contribution which the Chinese have made to their shared history, then the Chinese will be accepted and the "problem" resolved.

It has been suggested by some Indonesians that western writers are biased in favor of the Chinese.28 There may well be some truth in this, and the interest in anti-Chinese violence may help to explain it --there are few pribumi victims of violence at Chinese hands. But interethnic prejudice is not confined to ethnic Indonesians and it is not suggested that they alone should be painted warts and all. Nor is it suggested that the Chinese role in Indonesian history should be magnified out of its proper proportion. Opinions will doubtless differ as to how great it has been, but no good purpose will be served by trying to deny its existence.

We have moved well away from Somers Heidhues's book. It is scarcely fair of a reviewer to suggest that she should have written a different kind of book. Indeed it is difficult to conceive of a book dealing with the Southeast Asian Chinese in general would could follow all the alternative prescriptions proposed here, especially not one written by a sole author. Within the limitations of its scope and size, Southeast Asia's Chinese Minorities is the best book we have.

${ }^{28}$ Gondomono, "Tinjauan Buku." 